\title{
Maize silage as a finisher feed for Merino lambs
}

\author{
W.F.J. van de Vyver ${ }^{1 \#}$, J.A. Beukes ${ }^{1} \&$ R. Meeske ${ }^{1,2}$ \\ ${ }^{1}$ Department of Animal Sciences, Stellenbosch University, Matieland, South Africa \\ ${ }^{2}$ Western Cape Department of Agriculture, Outeniqua Research Farm, George, South Africa
}

(Received 12 October 2012; Accepted 12 August 2013; First published online 8 September 2013) of Animal Science

\begin{abstract}
A study was conducted to determine whether silage can be used as an ingredient in the finishing rations of Merino lambs. One of the concerns regarding the use of silage as the main ingredient of a sheep feed is its high moisture and neutral detergent fibre (NDF) content and relatively poor protein value. Forty lambs, in a four-way completely randomized block design, were used in a 60-day finishing study. The diets consisted of a control with no silage and three diets containing, on a dry matter (DM) basis $20 \%, 50 \%$ or $70 \%$ maize silage. With the exception of fibre (NDF and acid detergent fibre), all diets were formulated on an iso-nutrient level. Dry matter intake (DMI) decreased as the silage inclusion increased. This resulted in significant differences between the cumulative intake of the low and the high silage diets. The $20 \%$ and $50 \%$ silage diets resulted in higher dressing percentage than the control and $70 \%$ silage diet. It was concluded that silage can be successfully incorporated into sheep diets and that optimal inclusion levels need to be quantified within high specification feedlot diets.
\end{abstract}

Keywords: Feed intake, lamb growth, dressing percentage

\#Corresponding author: francois.vandevyver@tongaat.com

\section{Introduction}

Forage conservation plays an important role in animal production systems in South Africa. Large parts of the country have a low and variable rainfall with periodic droughts being the norm (Rouault, 2004). Furthermore, it is believed that livestock production, in developing countries, will have to double by 2020 to meet the ever-growing human population (Reddy et al., 2003). It is, therefore, of great importance for farmers to produce enough forage during the rainy season, not only to maximise production, but also to have enough in reserve in case of a drought.

There are two basic ways of forage conservation; hay making or the production of silage (McDonald et al., 2002). Silage production is favoured in some instances due to the fact that it is less weather dependent, less field and transportation losses occur and it is more palatable due to the cutting thereof at a younger growth stage, which means it contains less structural carbohydrates (Blaser, 1964). Silage is widely used as cost effective source of roughage in dairy cattle nutrition in South Africa. It is, however, not that commonly used in sheep production systems. European countries and Australia, on the other hand, make use of silage in their sheep enterprises to improve pasture utilisation, increase stocking rate, as a drought feed and also for the finishing of lambs in a feedlot (Stanley, 2003; Marley et al., 2007). The same principles can be applied to South Africa, not only to optimise pasture utilisation, but also to optimise sheep production to meet the evergrowing demand for animal protein. Sheep production systems in South Africa are traditionally extensive and sheep are more sensitive to silage quality than cattle, giving the impression that silage is not a practical or effective roughage source for sheep (Baumont et al., 2000). However, due to increasing feed prices and practices like conservation farming, farmers have to find ways to optimise their production systems. Using silage is proposed as one such option. Very little information is available in South Africa on the use of silage, optimized for certain nutrients, in sheep nutrition. The aim of this study was therefore to determine the 
optimum ratio of silage: concentrate in finishing diets for lambs in a feedlot. This study will lay the groundwork for future research.

\section{Materials and Methods}

Procedures used in this study were all approved by the Research ethics committee on animal care and use, Stellenbosch University (Ref: 11LV_VAN01).

Four dietary treatments, termed Control, $20 \%$ silage, 50\% silage and 70\% silage were prepared as follows: The dietary treatments were formulated to contain on a dry matter (DM) basis $0 \%, 20 \%, 50 \%$ or $70 \%$ silage in an effort to determine the effect that the silage has on lamb production under intensive feeding conditions. All the diets were formulated on an iso-nutrient basis, with the exception of neutral detergent fibre (NDF) which varied with silage inclusion levels. The physical and chemical composition of the treatments is presented in Table 1 . Whole crop maize was harvested at a DM content of $27 \%$ with a commercial silage harvester on Faircape, farm, Durbanville (Western Cape, South Africa). The untreated crop was compacted into 220 litre plastic drums and sealed in less than six hours. Drums were transported to Welgevallen Experimental Farm in Stellenbosch where it was further sealed with sand bags. It was left to ferment for 60 days before removing representative samples, using a silage drill, for proximate analysis. Raw materials for concentrate were mixed and pelleted at Mariendal Experimental Farm, Stellenbosch, South Africa. The control feed was prepared by Tanqua feeds, Riversonderend (Western Cape, South Africa), to supply nutrients at the same level as the experimental diets, except for fibre (NDF).

Table 1 Dietary ingredients and chemical composition of four diets fed to the Merino lambs

\begin{tabular}{|c|c|c|c|c|}
\hline \multirow{2}{*}{$\begin{array}{l}\text { Ingredients } \\
\text { (DM basis, g/kg) }\end{array}$} & \multirow[b]{2}{*}{ Control } & \multicolumn{3}{|c|}{ Maize inclusion level } \\
\hline & & $20 \%$ & $50 \%$ & $70 \%$ \\
\hline Maize silage (pH 3.62) & 0 & 200 & 500 & 700 \\
\hline Yellow maize & 545 & 513 & 303 & 144 \\
\hline Lucerne meal & 150 & 0 & 0 & 0 \\
\hline Cottonseed oil cake & 60 & 100 & 103 & 104 \\
\hline Molasses (meal) & 88 & 50 & 40 & 0 \\
\hline Salt & 5 & 5 & 5 & 5 \\
\hline Sodium bicarbonate & 20 & 20 & 20 & 20 \\
\hline Ammonium chloride & 5 & 5 & 5 & 5 \\
\hline Limestone & 18 & 18 & 18 & 18 \\
\hline Mono calcium phosphate & 3 & 3 & 3 & 3 \\
\hline Urea & 5 & 5 & 2 & 0 \\
\hline Mineral/vitamin & 1 & 1 & 1 & 1 \\
\hline Oat hay & 100 & 80 & 0 & 0 \\
\hline Total, g/kg & 1000 & 1000 & 1000 & 1000 \\
\hline \multicolumn{5}{|l|}{ Chemical composition, DM } \\
\hline Organic matter (g/kg) & 900.1 & 938.6 & 937.5 & 933.8 \\
\hline Ether extract $(\mathrm{g} / \mathrm{kg})$ & 19.2 & 32.8 & 31.2 & 36.8 \\
\hline Crude protein (g/kg) & 165.2 & 159 & 154.5 & 153.3 \\
\hline Acid detergent fibre (g/kg) & 204.1 & 121.6 & 184.6 & 204.1 \\
\hline Neutral detergent fibre (g/kg) & 421.7 & 242 & 316.7 & 341.8 \\
\hline Metabolisable energy (estimated MJ/kg) ${ }^{1}$ & 11.1 & 10.9 & 10.2 & 10.6 \\
\hline
\end{tabular}

${ }^{1}$ Estimated ME value based on feed formulation software data. 
Forty Merino lambs (wethers) of similar weight $(26.6 \pm 1.08 \mathrm{~kg})$ and at approximately $120 \mathrm{~d}$ of age were used in a 60-day finishing study. The lambs were fed indoors in a ventilated shed with slatted floor, with each animal housed separately in a $1.8 \mathrm{~m}$ x $1.2 \mathrm{~m}$ pen. On arrival they were tagged, dosed with Levicon (3 mL/10 kg live weight) for internal parasites and vaccinated with Multivax $P$ (1 mL) for pulpy kidney. Lambs also received a dose of Lacticon-S (35 mL) to help them adapt to the experimental diets. After the appropriate management practices were completed, the 40 animals were randomly divided into four groups of equal initial weights as a complete randomized design. Each group of lambs was assigned to one of the four dietary treatments and adapted over a seven day period. Individual intakes were determined during the adaptation period. Feeding troughs were cleaned every morning to maximise intake and prevent moulds and yeast forming on the silage. During the feeding period, feed was prepared fresh daily and given at 07:00 and 16:00. Water was supplied ad libitum. All refusals were bagged and weighed back once a week. Lambs were weighed once a week, before being fed, to determine average daily gain (ADG) and feed conversion ratio (FCR). Their individual body condition scores were also taken weekly.

All feed samples were analysed according to the AOAC standard methods for proximate composition. Additionally, samples for the silage specific analysis for $\mathrm{pH}$, starch and ammonia- $\mathrm{N}$ were sent to the University of Pretoria for analysis.

Data were analysed under the guidance of the Centre for statistical analysis, Stellenbosch University using Statistica 8.1 (2008).

\section{Results and Discussion}

One of the main concerns of using silage as an ingredient for the production of mutton is its high moisture content that can physically restrict the DM intake. Lambs fed the $70 \%$ silage diet had to constantly increase their intake, whereas lambs on the diets that had lower silage inclusion, did not have to adapt their intake as drastically to meet the nutrient demand (Figure 1). The lambs on the $50 \%$ and $70 \%$ silage diet had a physical restriction due to the low DM content and the high NDF intake and were not able to reach the same DM intakes over the 60 day study period as the lambs on the control and $20 \%$ silage diets. These animals constantly increased their intake as they grew physically bigger, but still was not able to reach the same intake as the sheep on the control or $20 \%$ diets as indicated by the lower cumulative DMI (Table 2).

Furthermore, the silage treatment groups were observed to consume their feed at a higher initial rate than the control group, indicating that silage inclusion had a positive effect on the palatability of the diet. This, however, should be quantified. From Figure 1, it can be seen that the weekly feed intake of the $20 \%$ silage treatment group was the highest $(P<0.05)$. With higher than $20 \%$ silage inclusion levels though, physical restriction started to limit DMI. Feed conversion ratios (FCR, kg feed to attain $1 \mathrm{~kg}$ weight gain) differed significantly between the groups. The $50 \%$ and $70 \%$ silage diets had the best FCR and differed significantly from the control and the $20 \%$ silage diet. The $20 \%$ silage diet had the highest $(7.91 \pm 0.401)$

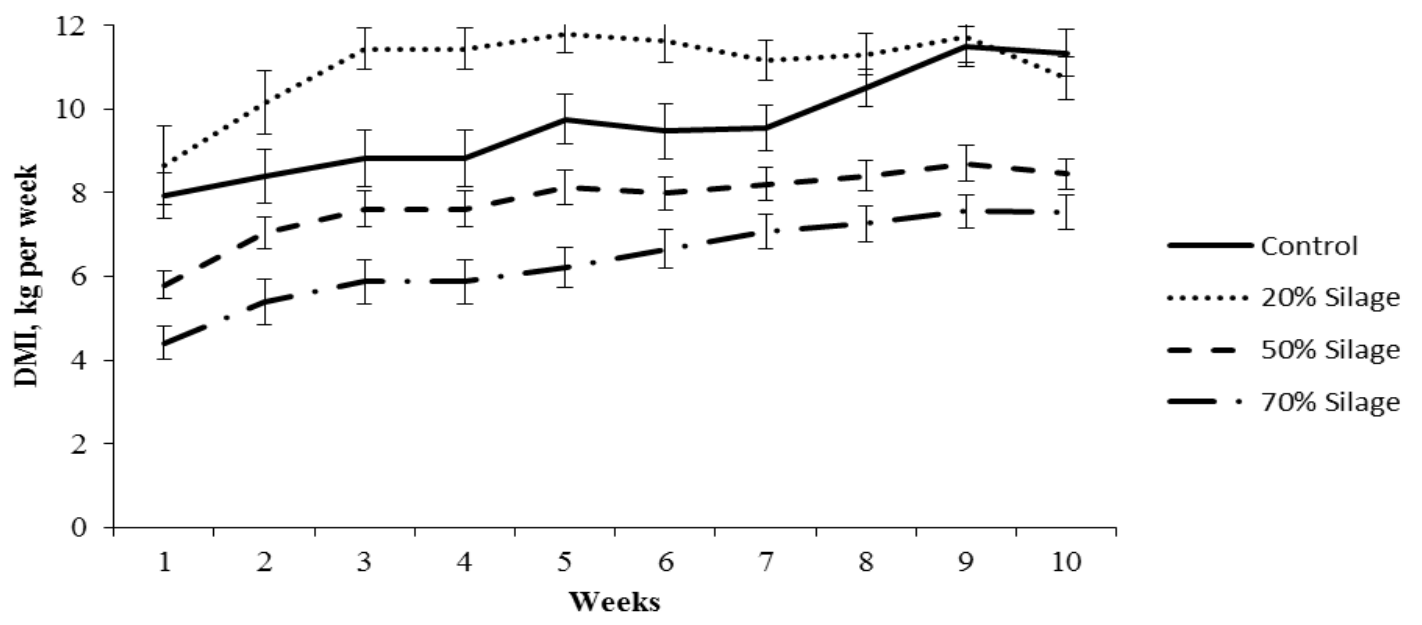

Figure 1 Weekly dry matter intake (DMI) of sheep fed four experimental diets containing $0 \%, 20 \%, 50 \%$ and $70 \%$ silage a DM basis. Error bars represent the SEM. 
FCR which is not optimal for the production of sheep in a feedlot. Future research is warranted to optimize these diets to specification levels for rapidly growing lambs, with special focus on undegradable protein (UDP) and carbohydrate sources.

Diets succeeded in supplying similar levels of energy and protein to the treatment animals as were confirmed by the growth performance results (Table 2). There were no differences between the groups for average daily gains and these growth rates, however low, were in agreement with results from Stanley (2003). Work done by Stanley (2003) showed that good quality, highly digestible legume silage can be used for the finishing of lambs. Live weight gains of $150 \mathrm{~g} / \mathrm{d}$ were observed when only legume silage was used and up to $300 \mathrm{~g} / \mathrm{d}$ gains were observed when replaced with $70 \%$ grain.

The dressing percentages were different. The groups fed the $20 \%$ and $50 \%$ silage diets had higher dressing percentages than the control group which is likely related to the feed ingredients of the diets as well as the dissimilar daily nutrient intake levels. The higher inclusion of cotton oilcake could have resulted in more lean growth.

Table 2 Mean $( \pm$ SE) growth parameters of Merino lambs fed four diets, differing in silage content

\begin{tabular}{|c|c|c|c|c|c|}
\hline & \multirow[b]{2}{*}{$\begin{array}{l}\text { Control } \\
\text { Diet } 1 \\
\end{array}$} & \multicolumn{3}{|c|}{ Maize silage inclusion level } & \multirow[b]{2}{*}{$P$-Value } \\
\hline & & $\begin{array}{c}20 \% \\
\text { Diet } 2 \\
\end{array}$ & $\begin{array}{c}50 \% \\
\text { Diet } 3 \\
\end{array}$ & $\begin{array}{c}70 \% \\
\text { Diet } 4 \\
\end{array}$ & \\
\hline Initial body weight (kg) & $26.25 \pm 1.114$ & $27.45 \pm 1.214$ & $26.95 \pm 1.613$ & $25.70 \pm 1.365$ & 0.804 \\
\hline Final body weight (kg) & $40.65 \pm 1.310$ & $40.25 \pm 1.276$ & $42.20 \pm 1.948$ & $38.20 \pm 1.780$ & 0.381 \\
\hline Body weight gain (kg) & $14.40 \pm 0.809$ & $12.80 \pm 0.814$ & $15.25 \pm 1.104$ & $12.50 \pm 0.888$ & 0.123 \\
\hline Cumulative feed intake (kg DM) & $87.27^{\mathrm{a}} \pm 3.822$ & $98.65^{\mathrm{a}} \pm 3.248$ & $70.37^{\mathrm{b}} \pm 3.026$ & $57.96^{\mathrm{b}} \pm 3.871$ & $<0.001$ \\
\hline Daily feed intake (kg DM) & $1.37 \pm 0.063$ & $1.57 \pm 0.052$ & $1.11 \pm 0.049$ & $0.91 \pm 0.062$ & $<0.001$ \\
\hline ADG (kg/day) & $0.23 \pm 0.013$ & $0.20 \pm 0.013$ & $0.24 \pm 0.018$ & $0.20 \pm 0.014$ & 0.123 \\
\hline FCR (kg feed/kg weight gain) & $6.13^{\mathrm{a}} \pm 0.248$ & $7.91^{\mathrm{b}} \pm 0.401$ & $4.74^{\mathrm{C}} \pm 0.265$ & $4.688^{\mathrm{C}} \pm 0.192$ & $<0.001$ \\
\hline Cold carcass weight (kg) & $17.14 \pm 0.771$ & $18.35 \pm 0.818$ & $19.85 \pm 1.020$ & $17.09 \pm 0.988$ & 0.123 \\
\hline Dressing percentage (\%) & $42.02^{\mathrm{a}} \pm 0.752$ & $45.58^{\mathrm{b}} \pm 1.277$ & $46.96^{\mathrm{b}} \pm 0.683$ & $44.55^{\mathrm{ab}} \pm 0.836$ & 0.004 \\
\hline
\end{tabular}

${ }^{\mathrm{a}, \mathrm{b}}$ Row means with different superscripts differ significantly at $P<0.05$.

ADG: average daily gain; FCR: feed conversion ratio.

\section{Conclusion}

It is evident from the data obtained that the DM intake of Merino lambs will decrease as the inclusion level of maize silage increases. This is mainly due to the high moisture and NDF content of the silage which physically restricts DMI. The results showed that silage can be used in diets up to inclusion levels of 50\% as an ingredient for the finishing of Merino lambs without negatively affecting the meat production of the animals. Silage inclusion of $20 \%$ or $50 \%$ increased the dressing percentage of the carcasses. However, ADG and FCR of sheep can be improved by formulating the diets at higher nutrient specification levels to sustain high growth rates. Further research is therefore proposed to optimise silage based diets by including increased UDP and carbohydrate rich ingredients to obtain the best possible growth rates.

\section{References}

Baumont, R., Prache, S., Meuret, M. \& Morand-Fehr, P., 2000. How forage characteristics influence behaviour and intake in small ruminants: a review. Livest. Prod. Sci. 64, 15-28.

Blaser, R., 1964. Symposium on forage utilization: Effects of fertility levels and stage of maturity on forage nutritive value. J. Anim. Sci. 23, 246-253.

Marley, C.L., Fychan, R., Fraser, M.D., Sanderson, R. \& Jones, R., 2007. Effects of feeding different ensiled forages on the productivity and nutrient-use efficiency of finishing lambs. Grass Forage Sci. 62 (1), $1-12$. 
McDonald, P., Greenhalgh, J. \& Edwards, R.A., 2002. Silage, hay, artificially dried forages, straw and chaff. In: Animal nutrition (sixth ed.). Pearson, Prentice Hall, England. Addison-Wesley Longman Ltd. pp. 515-537.

Reddy, B.V., Sanjana Reddy, P., Bidinger, F. \& Blümmel, M., 2003. Crop management factors influencing yield and quality of crop residues. Field Crop Res. 84 (1-2), 57-77.

Rouault, M., 2004. Intensity and spatial extension of drought in South Africa at different time scales. Water SA. 29 (4), 489-500.

Stanley, D., 2003. The role of silage in lamb-finishing systems [Online]. Available: http://grasslandnsw.com.au/news/wp-content/uploads/2011/09/Stanley-2003.pdf [2012, October 10].

Statsoft, 2008. Statistica version 8.1, StatSoft, Inc., Tulsa, OK. 